\title{
Overview and prospect: food and nutrition of seafarers on merchant ships
}

\author{
Marcus Oldenburg, Volker Harth, Hans-Joachim Jensen
}

Institute for Occupational and Maritime Medicine (ZfAM), University Medical Center Hamburg-Eppendorf, Germany

\begin{abstract}
During stay on board, seafarers have limited influence on quality and quantity of food over several months. Furthermore, the nutrition on board is characterised by different dietary habits in the multi-ethnic crews, differential food supply in crew's and officers' mess room and irregular mealtimes due to the shifts on board. Internationally, nutritional situation on board is not standardised, but reflects the flag-state standard. Up to date, there is only little comprehensive research published concerning food patterns of seafarers; these studies often lack in objective examination methods to estimate the actual food intake and activity-related energy requirements. Therefore, to examine the food and nutrition of seafarers, shipping companies should be interviewed about food provisions on board, and seafarers about eating habits in consideration of possible socio-cultural and psychological backgrounds for malnutrition. These studies should also encompass seafarers' health parameters related to nutrition on board (energy consumption, bioelectrical impedance analysis, ergospirometry and blood analysis). In total, further research directly on board is needed to know more about seafarers' food and nutrition situation at sea.
\end{abstract}

(Int Marit Health 2013; 64, 4: 191-194)

Key words: food, nutrition, exploration methods, seafarers

\section{FOOD ON BOARD}

European seafarers spend an average of 3-5 months on board, whereas Asian seafarers have contracts running 9-12 months at a stretch. Short port turnarounds cause phases of high workload to seamen. As a consequence, there are very limited opportunities for leisure time activities onshore.

On board food is usually served separately - for the mainly Asian crewmembers in the crew's mess room and for the often non-Asian superiors in the officers' mess room. Food in the mess rooms differs as an attempt to adapt food to ethnical habits (e.g. more rice in the crew's mess room).

Seafarers have very limited influence on quality and quantity of food over several months, especially during sea voyages on board of worldwide cruising merchant vessels. In current seafaring situation, warm meals are usually served 3 times a day. The following list summarises the actual dietary and living conditions on merchant ships:

- lack of self-determination in the selection of food;

- different dietary habits in multi-ethnic crews;
- differential food supply in crew's and officers' mess rooms;

- irregular mealtimes due to the shifts on board;

- limited opportunities for physical activities in leisure time;

- exceptionally high level of psychosocial stress in seafaring occupation (see below).

\section{LEGAL BACKGROUND FOR CATERING AND FOOD ON VESSELS}

The Maritime Labour Convention (2006) provides the legal basis for the living conditions on board, including food provisions [1]. Paragraph 3.2. sets out that: "Purpose: To ensure that seafarers have access to good quality food and drinking water provided under regulated hygienic conditions.

1. Each Member shall ensure that ships that fly its flag carry on board and serve food and drinking water of appropriate quality, nutritional value and quantity that adequately covers the requirements of the ship and

Dr Marcus Oldenburg, Department of Maritime Medicine, Hamburg Port Health Centre, Institute for Occupational and Maritime Medicine (ZfAM), Hamburg State

$\triangle$ Department for Health and Consumer Protection, University Medical Center Hamburg-Eppendorf, Seewartenstrasse 10, D-20459 Hamburg, Germany,

tel: +49 40428894 508, fax: +49 40428894 514, e-mail: marcus.oldenburg@bgv.hamburg.de 
takes into account the differing cultural and religious backgrounds.

2. Seafarers on board a ship shall be provided with food free of charge during the period of engagement.

3. Seafarers employed as ships' cooks with responsibility for food preparation must be trained and qualified for their position on board ship."

Precondition for hiring as a ship's cook is a minimum age of 18 years. In addition, seafarers need to prove the stipulated experience on board of a ship and a diploma of a certified cooking class. In Germany, an officially recognised training course lasting for 3 months is offered to acquaint already internationally experienced cooks with the European kitchen.

A critical appraisal of the Maritime Labour Convention (which has already been ratified by several states) reveals that the nutritional situation on board is neither standardised nor mandatory (see phrase "shall"), but adapted to the standard of each member state.

\section{RESEARCH ON THE DIET OF SEAFARERS}

According to the older examinations, the average energy consumption of the seamen in the merchant fleet was quantified to 3000-3500 kcal [2]. The individual energy consumption depends on the voyage episode of the ship (port or at sea), as well as the climatic conditions. In the 1960 s, the energy consumption of seafarers in the temperate zone was estimated around $3000 \mathrm{kcal}$ during moderate work and $3500 \mathrm{kcal}$ during hard work [3].

A recent study showed that $64 \%$ of seafarers were overweight and $23 \%$ of them were estimated as "obese" [4, 5]. A similar nutritional situation was already found in the 90s in Danish seafaring population [6]; 16\% of 351 male seafarers displayed a body mass index greater than $30 \mathrm{~kg} / \mathrm{m}^{2}$. The rate of overweight has increased during the last decade. In addition, Danish maritime students entering the maritime business showed already more overweight than other young people [7].

A Croatian study revealed that $75 \%$ of sailors $(n=174)$ were overweight, $80 \%$ showed increased cholesterol values, $40 \%$ increased plasma triglycerides values and 30\% increased blood glucose values [8]. Furthermore, Kendel et al. [9] demonstrated that an increased meat consumption in 20 Croatian seafarers of a container ship resulted in significantly increased saturated fatty acids and plasma cholesterol values.

A comparison of the nourishment among Lithuanian and Latvian seafarers at sea showed that Latvian seafarers more often than Lithuanian ones took e.g. boiled and roast potatoes, meat, chicken, eggs, coffee and juice [10].

In 2003, the Finnish maritime industry set up a nutritional project. The aim was to reduce the intake of salt and calories, and to increase the consumption of vegetables [11]. Based on the results of a dietary study among Chinese seafarers, the authors recommended a reduced intake of calories and fat, and an increased intake of vitamins during long sea voyages [12].

A study about US inland waterway merchant marine captains and pilots displayed a high prevalence of obesity (61\%), smoking (41\%), high triglycerides (42\%), low high density lipoprotein cholesterol (47\%), high blood pressure (42\%), high fasting glucose (22\%), and 3 or more features of the metabolic syndrome (39\%) [13].

A recent survey covering 104 seafarers in Germany revealed that [14]:

- $95 \%$ rated the food on board as "very important" or "important" for their level of job satisfaction and well-being in their daily routine;

- around $80 \%$ stated that they would prefer to eat healthier;

- $19 \%$ supplied themselves with food stored in their cabin;

- "fresh products, native food, variety and quality" were most often missed in shipboard provision;

- $20 \%$ took dietary supplements like pills ( $2 / 3$ of them were Filipinos).

In the latter study, higher dissatisfaction with food and nutrition on board was found in international tramp shipping only.

In summary, international studies on the nutritional situation of seafarers on board revealed that:

- there is only little comprehensive research published concerning food patterns of seafarers;

- data on eating habits of crewmembers were mostly collected by interviews without objective examination methods to estimate the actual food intake (e.g. standardised behavioural observation);

- the few available studies are almost exclusively related to the food consumption on board. The activity-related energy requirements stratified to different occupation groups were not assessed;

- identification of cardiovascular risk factors related to the eating habits requires objective procedures like blood analysis or ergospirometric stress tests. These procedures were applied only occasionally;

- the studies did not consider possible cultural differences in multi-ethnic crews.

\section{SEAFARERS' STRESS IN DAILY LIFE ABOARD}

\section{PSYCHOSOCIAL STRESS}

In general, psychosocial stress aboard is caused by excessive work demands, shift work, external control of work and lack of scope in decision-making [15-17]. The 
employment in the maritime sector is also associated with specific psychosocial stressors (including extremely long working hours, reduced duration and quality of sleep on board, permanent physical impacts such as ship movements, noise and vibration) $[18,19]$.

The high level of psychological stress in the seafaring profession can lead to psychosomatic disorders. In addition, this stress might increase the risk of developing coronary heart disease in this population. A possible malnutrition, combined with lack of exercise and high professional stress, represent crucial risk factors for cardiovascular disease. A study about the risk of seafarers for coronary artery disease demonstrated that almost $50 \%$ of the examined seafarers had an arterial hypertension, and 40\% elevated plasma triglyceride values. This was particularly related to the crew working in the engine room and in the galley [20]. Among Danish seafarers an increased cardiovascular mortality was observed, mainly caused by their shipboard lifestyle (such as unhealthy nutrition) [21].

\section{PHYSICAL STRESS}

It has been assumed that the energy demand of seafarers has decreased in the recent decades due to technical progress in ship operation [14]. However, up to date the crew and, in particular, the crew on deck and in the engine room is still exposed to heavy physical labour - especially during loading and unloading operations with heavy lashing materials and loading gear, or during repairs to the machine (sometimes under extreme heat conditions and constrained postures).

In addition, shift work on board can affect the nutritional behaviour of seafarers in terms of appetite disorders or even of "stress eating". Knowledge of additional energy requirements caused by increased muscular activity on board due to body-balancing movements in heavy seas is still lacking to date.

Leisure facilities on board are severely restricted; especially the possibilities of exercising outside working hours are reduced. Therefore, crew fitness rooms of large merchant ships are nowadays established and mostly equipped with weights, punching bags, treadmills or stationary bikes. According to the authors' experiences, these physical leisure facilities were only used by less than $20 \%$ of the crews on a regular basis. A Norwegian survey reveals that $70 \%$ of the asked seafarers did sports twice or more per week when at home, whereas only $39 \%$ exercised on board [22].

Overall, it can be stated that there is a high need for intensive examination of food and nutritional situation of seafarers under the specific working and living conditions on board.

\section{POSSIBLE METHODS TO EXAMINE THE FOOD AND NUTRITION SITUATION OF SEAFARERS}

\section{INTERVIEWS OF SHIPPING COMPANIES ABOUT FOOD PROVISIONS ON BOARD}

As a land-based approach, the food supply on board can be assessed by provision lists and the cooking recipes forwarded by the shipping company. In this context, possible calculation and realisation constraints for the cook by the shipping companies like a low catering budget must be taken into consideration. Furthermore, the orders of the captain and limited possibilities of fresh food supply and storage during long sea voyages (with limited access to food-outfitting ports) have to be taken into account.

\section{INTERVIEW OF SEAFARERS ABOUT SHIPBOARD EATING HABITS}

Standardised questionnaires like the "24-hour recall" (for the last day) or the "Food Frequency Questionnaire" (for the past months) can evaluate individual food intake for a particular period of time [23]. Due to long sea voyages and short port stay - particularly in worldwide cruising merchant vessels - there is only little chance for the intake of ship-external food sources, which reduces a probable bias compared to dietary studies in other contexts ashore.

\section{INTERVIEW OF SEAFARERS TO COLLECT DATA OF POSSIBLE SOCIO-CULTURAL AND PSYCHOLOGICAL CAUSES FOR MALNUTRITION}

Existing standardised questionnaires for the assessment of living and working conditions (e.g. the causes for malnutrition) in the general population ashore do not sufficiently cover specific conditions in multicultural crews on board [24]. Based on the "Seafaring-Specific Questionnaire" developed by Oldenburg et al. [18] and Jensen et al. [25] and existing standardised questionnaires from the European cultural area, a semi-structured interviewguide could be developed and applied aboard. Priorities of this interview guide should be:

- lifestyle and level of stress experienced by seafarers;

- mental well-being and social discrimination;

- body satisfaction;

- cultural values and intuitive dietary preferences;

- nutritional situation and eating habits in the society of origin;

- group processes and eating behaviour;

- food as an emotion regulator;

- self-management skills;

- socio-economic status. 


\section{DETECTION OF SEAFARERS' HEALTH PARAMETERS RELATED TO NUTRITION ON BOARD}

In order to analyse whether malnutrition or an increased risk for cardiovascular disease is present among the seafarers, the following objective parameters should be collected:

- anthropometric data: height, weight, body mass index and waist-hip ratio;

- energy consumption: with activity monitors like the "BodyMedia SenseWear armband" the energy consumption can be determined fairly accurately and at the same time be compared with the estimated caloric intake [26];

- bioelectrical impedance analysis: this procedure provides physiological data to estimate (3 component model) the body composition with fluid and hydration diagnosis (such as body cell mass, muscle mass and fat mass, water balance - particularly the differentiation between the intracellular and extracellular water content). For this purpose, the device Akern BIA 101 can be used for instance [27];

- ergospirometry: to measure the seafarers' cardiopulmonary performance, ergospirometry can be conducted for example with the climbing stage aboard. In addition, by performing a mobile cardiopulmonary exercise test, calorie consumption and respiratory gases can be collected during a normal working day. A suitable device for these tests is for example the Oxycon Mobile produced by Viasys [28];

- blood analysis: complete blood count, lipids (total cholesterol, LDL, HDL, triglycerides), uric acid, liver function values (GOT/AST, GPT/ALT, GGT), blood sugar, thyroid hormones and vitamin D.

\section{CONCLUSIONS}

In summary, the issue of food and nutrition of crews aboard merchant vessels is still topical in the maritime research. Based on the results of nutritional maritime studies, strategies need to be developed in order to improve the food and nutrition situation aboard. Furthermore, considering the prevention of possibly increased risk for cardiovascular disease, concrete and practical implementation measures are of the utmost importance.

\section{REFERENCES}

1. Maritime Labour Convention (2006). http://www.ilo.org/global/ standards/maritime-labour-convention/WCMS_090250/lang-en/ index.htm. Accessed at August 2013.

2. Zorn M. The seafarers' food. Handbook of nautical medicine. Hrgs: Goethe, Berlin 1984

3. Kierst W. Bad effects of improper nutrition during the work on sea. Bulletin of the Institute of Marine Medicine Gdansk 1966.

4. Hoyer JL, Hansen H. Overweight among Nordic male seafarers. $8^{\text {th }}$ International Symposium of Maritime Health 2005, Rijeka, Croatia.

5. Hoyer JL, Hansen HL. Obesity among Danish seafarers. Int Marit Health 2005; 56: 48-55.

6. Hansen H, Dahl S, Bertelsen B, Brix J. Lifestyle, nutritional status and working conditions of Danish sailors. Travel Med Int 1994; 12: 139-143.

7. Hansen HL, Hjarnoe L, Jepsen JR. Obesity continues to be a major health risk for Danish seafarers and fishermen. Int Marit Health 2011; 62: 98-103.
8. Pancic M, Ricka-Zauhar Z, Blazevic M. Analysis of risk factors and assessment of exposure to coronary diseases in seamen. $8^{\text {th }} \mathrm{In}$ ternational Symposium of Maritime Health 2005, Rijeka, Croatia.

9. Kendel G, Pavicic-Zezelj S, Micovic V. Evaluation of nutrition and risk of cardiovascular disease among seamen. $8^{\text {th }}$ International Symposium of Maritime Health 2005, Rijeka, Croatia.

10. Salyga J. Comparative analysis of nourishment of Lithuanian and Latvian seafarers at sea. Medicina (Kaunas) 2005; 41: 781-786.

11. Saarni H, Niemi L. Health promotion among Finnish seafarers: Trimmare project. $9^{\text {th }}$ International Symposium of Maritime Health 2007, Esbjerg, Denmark.

12. Hongguang J, Haiming W, Kaiji L. A nutrition survey of seamen on board of oceanliner. Chin J Naut Med 1996; 3: 80-84.

13. Scovill SM, Roberts TK, McCarty DJ. Health characteristics of inland waterway merchant marine captains and pilots. Occup Med (Lond) 2012; 62: 638-641.

14. Wittkowski. Ernährung auf Seeschiffen in der Kauffahrteischifffahrt [Nutrition onboard seagoing merchant vessels]. Fachbereich Seefahrt, Elsfleth, Jadehochschule 2011.

15. Stansfeld S, Candy B. Psychosocial work environment and mental health: a meta-analytic review. Scand J Work Environ Health 2006; 32: 443-462.

16. Greiner BA, Krause N. Expert-observer assessment of job characteristics. In: Schnall P, Belkic K, Landsbergis P, Baker D (eds.) The workplace and cardiovascular disease. Occ Med 2000; 15: 175-183.

17. Karasek R, Brisson C, Kawakami N, Houtman I, Bongers P, Amick B. The job content questionnaire (JCQ): An instrument for internationally comparative assessments of psychosocial job characteristics. J Occup Health Psychol 1998; 3: 322-355.

18. Oldenburg M, Jensen HJ, Latza U, Baur X. Seafaring stressors aboard merchant and passenger ships. Int J Public Health 2009; 54: 96-105.

19. Oldenburg M, Hogan B, Jensen HJ. Systematic review of maritime field studies about stress and strain in seafaring. Int Arch Occup Environ Health 2012; 86: 1-15.

20. Oldenburg M, Jensen H-J, Latza U, Baur X. Coronary risks among seafarers aboard German-flagged ships. Int Arch Occup Environ Health 2008; 81: 735-741.

21. Hansen HL, Pedersen G. Influence of occupational accidents and deaths related to lifestyle on mortality among merchant seafarers. Int J Epidemiol. 1996; 25: 1237-1243.

22. Geving IH, Jørgensen KU, Thi MS, Sandsund M. Physical activity levels among offshore fleet seafarers. Int Marit Health 2007; 58: 103-114.

23. Bingham SA, Gill C, Welch A et al. Comparison of dietary assessment methods in nutritional epidemiology: weighed records $v .24 \mathrm{~h}$ recalls, food-frequency questionnaires and estimated-diet records. $\mathrm{Br} J$ Nutr 1994; 72: 619-643.

24. Leszczyńska I, Jeżewska M, Jaremin B. Work-related stress at sea. Possibilities of research and measures of stress. Int Marit Health 2008; 59: 93-102.

25. Jensen HJ, Hansen DP, Oldenburg M. Untersuchungsmethode zur Erfassung psychischer Fehlbelastungen und Fehlbeanspruchungen in der Seeschifffahrt [Methods for examination of elevated stress and strain in seafaring]. Arbeitsmedizin Sozialmedizin, Umweltmedizin 2011; 46: 156.

26. Johannsen DL, Calabro MA, Stewart J, Franke W, Rood JC, Welk GJ. Accuracy of armband monitors for measuring daily energy expenditure in healthy adults. Med Sci Sports Exerc 2010; 42: 2134-2140.

27. Vienna A, Hauser G. A qualitative approach to assessing body compartments using bioelectrical variables. Coll Antropol 1999; 23: 461-472.

28. Eriksson J, Rosdahl H, Schantz P. Validity of the Oxycon Mobile metabolic system under field measuring conditions. Eur J Appl Physiol 2012; 112: 345-355 